\title{
The gamma system, pathology and therapeutics
}

\author{
Ricardo Horacio DE LELlis \\ M.D. \\ Docente auturizado de Pediatriz de la facultad de Medicinz de Buenos Aires, Medico de los Hospitale \\ del Hospital de Pediatria Pedro de Elizalde, Buenos Aires
}

\begin{abstract}
Hypothesis for the integration of childhood immunity
Advances in the immunobiology of the thymus, immunological competence and immune response have made it necessary to attempt a provisional scheme to describe the interplay of 'germ and soil'. Good \& Papermaster (1964) have emphasized the significance of adaptive immunity which is characterized by an immunological memory, the second phase of the homograft reaction and the secondary immunological response. Recently the thymus has been ascribed a fundamental place in the phylogenetic and ontogenetic development of the lymphoid system of the higher vertebrates. The inheritance of genetic information for the development of this potential is transmitted through the lymphoid system of mammals (Fig. 1). The thymus may be involved in the differentiation and maintenance of the potential for antibody synthesis, but the maintenance of the synthesis of antibodies takes place in mature, immunocompetent cells (Talmage \& Claman, 1964).
\end{abstract}

Both lymphopoiesis and immunogenesis have different aspects depending upon whether they are considered in the context of the thymus or the peripheral lymphoid system. It can be assumed that there exists a central (thymic) and peripheral lymphopoiesis in the same way that there is thymic and peripheral immunogenesis. The first is characterized, at any rate in the early periods of life, by increased proliferation of lymphoid cells, the extent of which appears to be genetically determined and to decline with age (Metcalf, 1956). Peripheral lymphopoiesis would thus be thymus-dependent and increasingly antigen-dependent with the progress of maturation.

Central immunogenesis would be characterized by the production of competent (uncommitted or ' $x$ ') cells (Ford, Gowans \& McCullagh, 1966; Sterzl, 1966) or by the differentiation of lymphocytes, which, once they had reached a certain degree of differentiation, would be liberated into the bloodstream (Miller, 1961). Secondly the provision of a milieu of immunological tolerance for lymphoid cells would allow the differentiation of immunologically competent cells (Miller, Marshall \& White, 1962;
Ford \& Micklem, 1963; Harris \& Ford, 1964). Thus bone-marrow cells may replace the thymus after radiation induced atrophy of the thymus. These cells may acquire 'distinguishing' properties in the thymus (Metcalfe, 1964; Auerbach, 1966) and lose $c$ the property of repopulating the bone marrow (Dustin \& Gregorie, 1931; Ford, 1966).

\section{Lymphopoiesis in the thymus}

In the initial stages of ontogenesis, thymic $\vec{T}$ lymphopoiesis appears to be autonomous. In $\frac{\mathbb{O}}{O}$ succeeding stages it may derive from circulating precursors which settle in the thymus and differentiate (Trinin \& Law, 1963; Sainte Marie \& Leblonos 1964); Ford, 1966. Fragments of thymus in tissue culture becomes differentiated by the seventh day The spleen and bone-marrow do not form lymphoid tissue, whereas the thymus forms lymphoid tissue independently (Auerbach, 1966). Thymic lymphocytes are of entodermal origin in contrast to peripheral lymphocytes which are of mesenchymal origin (Sainte Marie \& Leblond, 1964).

The thymus differs from the remainder of the lymphoid system in the following respects: (1) the mitotic index is ten times greater in the thymus than in peripheral lymphoid organs; (2) it becomes involuted with age; (3) the mitotic indices are unaffected by antigenic stimulation; (4) the weight is uninfluenced by peripheral lymphoid tissue; (5) implants of thymic tissue grow in the same way in thymectomized subjects as in controls; and (6) its proliferative activity is not reduced by extraneous antigens, and is comparable in intensity to that of many tumour cells.

The proliferative stimulus would not operate diffusely since the thymus is constituted by independent subunits, each with its own source of proliferative stimulation. It may originate in the epithelial cells of the medulla or indirectly via the reticular cells of the cortex, possibly mediated by a humoral factor (Metcalf, 1966).

Clark (1966) confirmed the existence of secretory material in the epithelial cells of mouse thymus medulla, and defined three stages of maturation in 


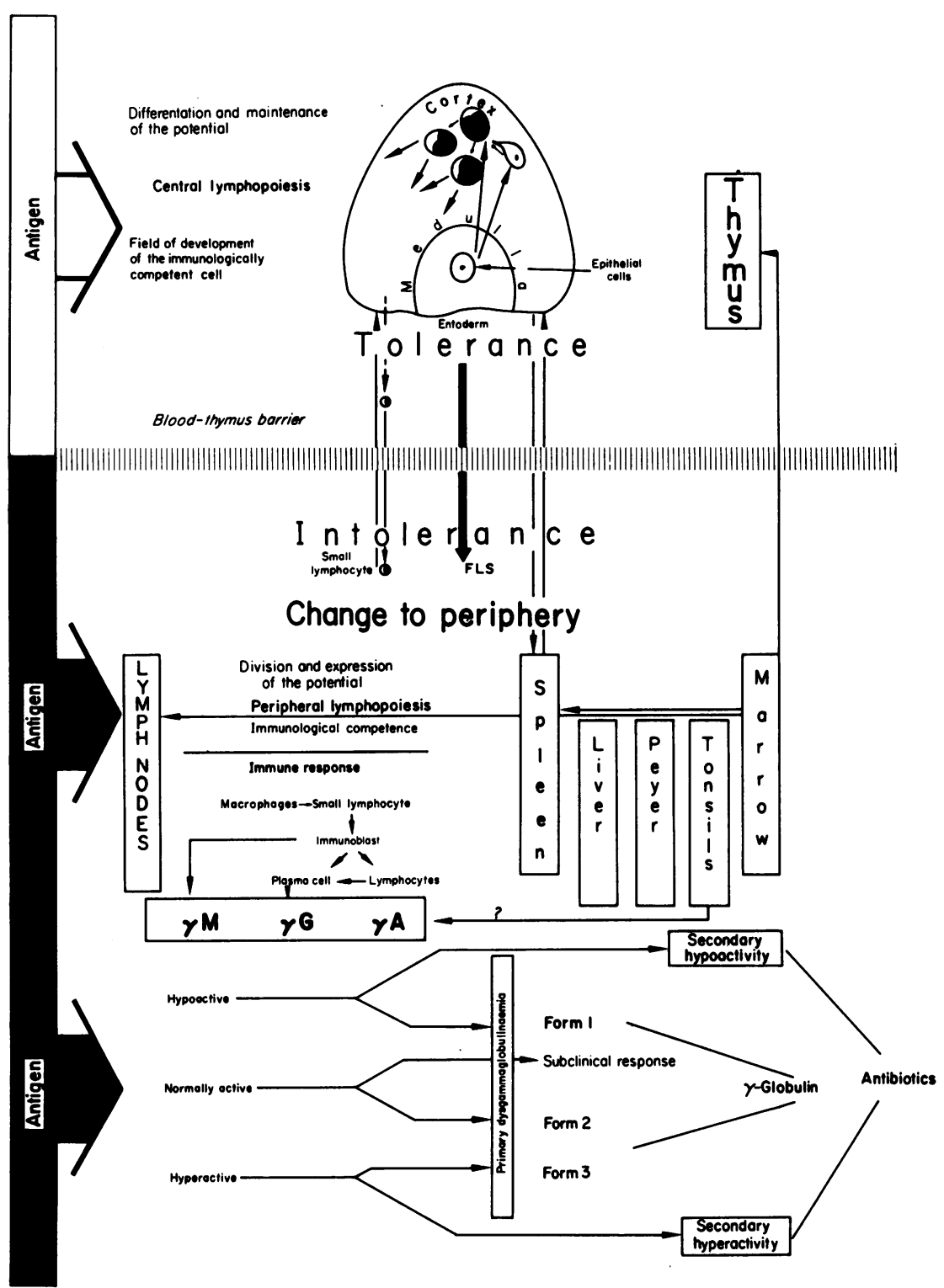

Fig. 1. Hypothesis for immunological integration in children. Inherited genetic information.

relation to secretory content of a mucopolusaccharide acid sulphate: (1) densely basophilic granules before birth, (2) clusters of vacuoles after birth, and (3) PAS-sensitive amorphous inclusion material 15 days after birth.

In summary, thymic lymphoiesis would appear to be autonomous in the initial stages of ontogenesis, it is stimulated by the epithelial cells of the medulla acting as subunits of stimulation and developing according to an irreversible sequence: entoderm, epithelial cell, large, medium and small lymphocytes (Dustin \& Gregoire, 1931). The last of these are the most differentiated (thymocytes) and are the product of successive reduction mitoses (Sainte Marie \& Leblond, 1964).

\section{Fate of the thymocytes}

The thymus produces in its cortex more lymphocytes than it needs for local development. The high mitotic activity in relation to the stability of the 
organ raises two possibilities, that either the small lymphocyte degenerates and is destroyed in the thymus or that it migrates. The first alternative is most likely since the ratio of the number of mitotic cells to the number of pyknotic cells is related to the weight of the organ and falls with involution. The second alternative is suggested by the effects of thymectomy and of thymic extract on peripheral lymphopoiesis. A direct or humoral stimulus might regulate the production and maturation of the peripheral lymphoid system.

Some authors believe that the thymocyte never leaves the thymus, but that nucleoproteins accumulated in pyknotic cells are discharged and utilised in rapid cell division elsewhere (Ford, 1966). The thymus would thus be a reservoir for DNA which could be utilized at any time (Bryant, 1962).

Transplantation of thymocytes and lymphocytes labelled with ${ }^{32} \mathrm{P}$ gives rise in the liver to both homologous and heterologous thymocytes (Fichtelius \& Bryant, 1964). Labelled chromosome studies have demonstrated that lymphoid cells join the peripheral lymphatic system after a period of residence in the thymus (Ford \& Micklem, 1963).

The difficulty in establishing the migration of the thymocyte beyond doubt resides in the difficulty of labelling thymic cells without simultaneousiy labelling lymphoid cells. Nossal injected thymidine directly into the thymus of the guinea-pig with minimal involvement of the other organs and found a ratio of one labelled thymic cell per 50,000 in the lymph nodes. While confirming the migration of thymocytes to the periphery, this low incidence indicated that this occurs to a limited extent (Nossal, 1964; Metcalf, 1964).

\section{The thymic barrier and immunological tolerance}

When the thymocyte leaves the thymus, it abandons an environment of immunological tolerance. Immunotolerance is a state of non-reactivity to agents which are antigenic in other circumstances, and is associated with the differentiation between self and non-self established during embryonic life (Burnet, 1961 ; Mackay \& Burnet, 1963). It is specific for antigens to which the immature animal is exposed and its persistence often depends upon their continued existence within the recipient tissues. The antigen may thus direct the lymphoid cell towards either immunity or tolerance. The dose and age are factors which influence this although the cellular mechanism is not understood. Tolerance can be induced by low and persistent concentration of the antigen but can continue without it in a tolerant cell population. Tolerance, which is permanent, may be attained by thymectomy or by the maintenance of the antigen in diffuse form until lymphogenesis has been exhausted (Brent \& Gowland, 1963;
Claman \& Talmage, 1963; Nossal \& Mitchell, 1966).

A series of experimental investigations have demonstrated that thymic lymphoid cells can produce antibodies (Miller et al., 1962), can become immunologically competent and can re-establish the $\stackrel{0}{\rightarrow}$ immunological activity of thymectomized animals (Yunis et al., 1964). The thymocytes of mice and rats immunized with tetanus toxin are capable of activat- $\frac{\bar{D}}{\vec{D}}$ ing an immune response when transferred to $\stackrel{\varnothing}{\propto}$ isologous, irradiated recipients (Stoner \& Bond, is 1963). Thymic tissue transplanted to the anterior chamber of the eye of an irradiated mouse, produces a specific antibody response, and isolated thymic cells are also capable of producing a reaction between graft and host in newly born mice (Miller, 1964).

Despite this the potential immune response of the lymphoid thymic cells in the intact animal is impaired by the existence of a blood-thymus barrier so that the antigen cannot be fixed by the thymus. In contrast to other lymphoid tissue in the normal animal neither secondary follicles nor plasma cells are developed (Miller et al., 1962).

The blood-thymus barrier has, however, an evolving character and is not complete for all antigens. In adult rats there is a partial barrier but in the newborn it is ineffective for both soluble antip gens (bovine serum albumin) and specific (\$ adelaide) antigens. It can be shown that the barries begins to develop in the rat after the 3rd week of life and is linked in the 6th week to restricted permeability similar to that of the adult (Nossal, 1966).

\section{Immunological competence}

The spread to the periphery of the lymphoid system (Archer et al., 1962) forms a process of maturation with phylo- and ontogenetic specificities and serves to integrate the individual into distinct levels of potential immune response according to two main logical and functional thymus-dependent differentiation, secondly, the progressive development at the periphery of the antigen-dependent immunological response.

Peripheral lymphopoiesis differs from thymic lymphopoiesis by the differing sensitivites of the two systems to corticosteroids, sex hormones, irradiation and inanition, all of which have a smaller effect upon the peripheral system (Dougherty, 1952). Two mechanisms are utilized, the exposure of the lymphoid cells of these organs to external antigens, the other is not fully understood because of the difficulty in measuring the liberation of cells preformed in the thymus. It is not known whether the thymic precursors in the peripheral lymphoid system are stimulated by a factor for lymphopoietic stimulation (FLS) or whether the stimulus is a direct one 
to the committed cells. With both precompetence or competence, FLS might stimulate the maturation of the non-competent cell (Metcalf, 1964). Peripheral thymus-dependent lymphopoiesis is affected by thymectomy and thymic extracts as in the case of defective peripheral lymphoid development with normal thymic lymphopoiesis in 'germ free' development, where antigenic stimulation has been reduced to a minimum (Gordon, 1959). Immunological competence is manifest beyond the thymic barrier under the influence of antigenic stimulation even though much of this may be thymus-dependent. It appears essential even in adult life to maintain a pool of immunologically competent cells.

The effect of thymectomy in mice upon the development of immune capacity by peripheral lymphoid tissue diminishes progressively with age. Even if this procedure does not provoke in the adult mouse the same immediate impairment as in the newborn, this decline appears 6-9 months later. The delay may be due to the existence of a reservoir of immunologically competent cells produced before the thymectomy (Miller, 1964). The same considerations apply to the 'germ free' mouse in which the immunological capacity of the cells of the spleen increases progressively until 8 months of age, but then declines (Makinodan \& Petersen, 1967).

The colonization by the thymocyte of the peripheral lymphoid system (Fichtelius \& Diderholm, 1959; Everett, Rieke \& Caffrey, 1964) demonstrates that normal thymic cells and some cells of other origin which have resided in the thymus, have a particular capacity to establish and grow in the lymph node (Ford, 1966). During the first stages of ontogenesis the thymus produces lymphocytes in the epithelial cells of the medulla, they migrate and settle in the spleen and in the lymphatic nodes (Levey, Trinin \& Lay, 1963; Feldman \& Mekori, 1966). Thus cells of the spleen in the 15-day-old chick are of thymic origin (Aspinall et al., 1963) and small lymphocytes in the thoracic duct of the rat labelled with tritiated thymidine 'home' to the spleen, lymph nodes and Peyer's patches (Gowans, 1964).

The FLS theory was originally proposed by Metcalf (1956). Thermolabile extract from adult mice injected into newborn rats and the thymectomized adult caused an increase in circulating lymphocytes which was attributed to lymphopoietic stimulation (Metcalf, 1956). Intraperitoneal capsules containing newborn thymic tissue implanted into thymectomized mice, are able to make good deficient FLS (Osoba \& Miller, 1964).

FLS is produced by the reticulo-endothelial cells of the medulla, is filtrable, thermolabile, non-dialysable. It is present in normal blood, and increased concentrations occur in leukaemia. Extract of the thymus of adult mice and of human subjects produce lymphocytosis in newborn and thymectomized adult mice (Metcalf, 1964). Extracts of thymus injected into adult rats rendered lymphopenic by irradiation, restore the number of circulating lymphocytes to normal values (Camblin \& Bridges, 1964). Extracts of rabbit thymus irradiated with doses sufficient to destroy the lymphoid cells injected into adult rats produce a lymphoid hyperplasia (Gregoire \& Duchateau, 1956), cell free extracts of thymus also stimulate lymphopoiesis (Kunii, Firth \& Berwick, 1966). Finally, extracts of thymus from rats, mice and calves, cause an increase in the uptake of radioactive precursors of DNA and ganglion proteins by mouse lymph nodes, but extracts of other lymphoid organs and external proteins give negative results (Klein, Goldstein \& White, 1965).

The stimulation of lymphoid development in the germ-free animal produces appreciable mitotic activity in the cells of lymphoid tissues, which precedes antibody production (Leduc, Coons \& Connoly, 1955). This stimulation thus seems to accelerate thymus-induced production in these peripheral organs (Gluberson \& Auerbach, 1964; Leuchars, Davis \& Koller, 1966).

The repeated exposure to infection would seem to initiate the conditions of regional immunity which free these centres from dependence on the thymus. The increase in the concentration of antibodies in the blood leads to a progressive decline in thymusdependent lymphopoiesis and immunogenesis (Albright, Capalbo \& Makinodan, 1964).

\section{The immune response}

There is no agreement as to whether the lymphoid cell becomes competent within the thymus (Sterzl, 1966) as thymus cells derived from the ectoderm in early life (Metcalf, 1966) or outside the thymus through the action of FLS (Taylor, 1963; Defendi, Roosa \& Koprowski, 1966).

The first response converts the competent cell into a committed one and this then produces the secondary response by means of the small lymphocyte which is the carrier of the immune memory (Fichtelius \& Diderholm, 1959). Two classes of small lymphocyte seem to exist: one potentially capable of initiating a response (competent or uncommitted) and the other with the capacity only for a specific response (committed). Sterzl has named those cells which acquire their immunological competence before migrating to the peripheral tissues ' $x$ ' cells, ' $y$ ' cells those which are produced in response to activation by them, and ' $z$ ' cells those which differentiate from the ' $y$ ' cell in the secondary response (Ford et al., 1966; Sterzl, 1966).

The 'immunocytic complex' (Dameshek, 1966) includes cellular forms which participate in prolifera- 
tive activity induced by the antigen. It includes three stages: (1) phagocytosis during which the antigen is broken up by the macrophages (histiocytes); (2) information in which an aggregation of lymphocytes with foot appendages obtain specific information from the macrophages; and (3) immunological activity: some of these lymphocytes differentiate into large pironinophilic cells (immunoblasts) which become dedifferentiated into two cellular forms according to the type of stimulating antigen, lymphocytes, and plasma cells (Dameshek, 1966).

The passage of information from macrophage to lymphocyte has been suggested (McFarland \& Heilmann, 1965) and antigen has been shown to form a complex with macrophage RNA, which is capable of stimulating antibody formation by lymph node cells (Fischman \& Alder, 1963; Nossal, Ada \& Austin, 1964; Askonas \& Rhodes, 1965; Friedman, Stavitsky \& Solomon, 1965. It is not enough to find antigen in the lymphocyte; it is also necessary to determine the exact origin of the plasma cell whose division is preceded by that of the large basophilic blast cells (Schodley, 1961 ; Congdom \& Duda, 1961; Nossal \& Makela, 1962; Dutton, Eady \& Belman, 1963). Two lines of lymphoid cells develop into cells which contain antibodies, plasma cells and lymphokinecytes. The latter are medium and small lymphocytes which contain specific antibody and incorporate labelled DNA from precursors resembling blast cells. Adult plasma cells do not divide and can be considered terminal cells. Some small lymphocytes have an endoplasmic reticular network and contain or produce antibody. In conclusion it would seem likely that plasma cells are derived from lymphocytes.

\section{Immunoglobulins}

The immunoglobulins are the final product of the immunocytic complex, the product of the immunologically competent cell. The synthesis of $\gamma \mathrm{A}, \gamma \mathrm{M}$, $\gamma \mathrm{G}$, the most studied immunoglobulins of 'Gamma system' (Heremans, 1960), appear to have a sequence whose stages have hardly been elucidated. $\gamma \mathbf{M}$ is produced as the first humoral response to antigenic stimulation; $\gamma \mathrm{G}$ results from the secretion of plasma cells in the second stage of the mechanism set into motion by the action of the antigen. The early mobilization of $\gamma \mathrm{M}$ with the production of poorly specific antibodies would seem to represent a rudimentary onto- and phylogenetic mechanism initiated by various natural antigens, usually related to viruses, Gram-negative bacteria, hydrocarbon antigens and iso- and autoantibodies (Schultze, 1959; Schwick, 1966). $\gamma \mathrm{G}$ is the vehicle for highly specific and delayed antibodies; so that infections increased the potential of $\gamma \mathrm{G}$ in childhood. Our studies on the electrophoretic fraction of $\gamma \mathrm{G}$ which migrates rapidly have demonstrated a recently acquired immune role in contrast to $\gamma \mathbf{M}$ and $\gamma \mathbf{G}$ in their complexes (de Lellis \& Winckler, 1966).

Sahiar \& Schwartz (1964) suggested a possible feed-back sequence in the immune response starting with the production of $\gamma \mathrm{M}$. This would be produced by the immunoblast and by 6-mercaptopurine, and would block the production of $\gamma \mathrm{G} . \gamma \mathrm{A}$ is a vehicle for antibodies and secretions, but its origin has not yet been determined.

\section{Primary and secondary dysgammaglobulinaemias}

Our experience of changes in the system in states of susceptibility to infection, particularly in the 1st year of life, has enabled us to define by clinical, haematological, therapeutic criteria, three levels of response. Both types of autonomous lymphopoiesis, differentiate the immunologically competent cell, thymusdependent in the embryonic state, and in more advanced stages, from extrathymic precursors. The progressive development of immunological competence is determined in close relation to antigen induced peripheral lymphopoiesis, initiated by dissemination of the thymocyte and influenced either directly or indirectly through FLS. The system is subject to the participation of the immunocytie complex in the immune response and the production of the immunological memory.

The whole of the process of peripheral develop? ment possesses quantitative and qualitative aspects which are closely linked to the levels of integration which we are proposing. The child in early infancy has at least three modes of clinical response: which can clinically be identified by: (a) occurrence during the 2nd month of life; (b) cyclical infections; (c) ineffectiveness of antibiotics and chemotherapy in preventing reinfections; and (d) response to therapy with $\gamma$-globulin.

Form 1: Fever and lymphoid hypertrophy; form 2, catarrhal, with progressive lymphoid development and form 3, spasmodic bronchitis with lymphoid hypertrophy. The $\gamma$ system has a differential pattern for each clinical form especially regarding the development of $\gamma \mathrm{A}$ and rapid $\gamma \mathrm{G}$. The former is absent in the febrile form, normal in the catarrhal, and frequently raised in form 3. Rapid $\gamma G$ is absent in the more immature form, decreased in form 2 and normal in form 3 (de Lellis \& Winckler, 1967, 1968).

Apart from situations in which the 'soil' plays a decisive part in the infection (primary dysgammaglobulinaemias) the remaining conditions are more diffuse and bacterial or viral antigens are of comparatively greater significance. In these the course may be either secondary hyperimmunoglobulinaemia, in which the overproduction of immuno- 
globulins is related to the duration of contact between the antigen and the immune systems, or secondary hypoimmunoglobulinaemia in which deficient synthesis, accelerated catabolism or increased secretory loss from the immunologically competent cell occur.

From the therapeutic view point the primary dysgammaglobulinaemias are specifically influenced by therapeutic $\gamma$-globulin while, unlike the secondary dysgammaglobulinaemias, they are insensitive to the antibiotics and chemotherapeutic agents. The therapeutic effect of the $\gamma$-globulin and the predominant symptomatology of the primary dysgammaglobulinaemias suggest certain features of their pathophysiology. Form 1 can be explained in the terms of a stimulant (or deficiency of a depressant) which enters allosteric combination with the repressing substance (aporepressant) of the regulating gene, and initiates the mechanism of the operant gene (Jacob \& Monod, 1961). This would explain the therapeutic effectiveness of small doses of $\gamma$-globulin. In the children studied effects were similar with doses of $150,300,600$ and $900 \mathrm{mg}$.

At the cellular level another explanation for the failure of differentiation of precursors into plasma cells may be due to an inability to circumscribe the antigen (Nossal \& Mitchell, 1966). The passage of the antigen into solution may disseminate the antigen without blockage in any lymphoid sector and thus determine the clinical picture in prolonged febrile illness. There may also exist low doses of antigen or failure in the processing of this by the macrophages. This could be considered to be a state of clinical tolerance to the antigen with a permeable thymic barrier.

In dysgammaglobulinaemia 2 a change in these circumstances and the degree of maturation would allow a rapid increase in the immune response in response to the succession of infectious experiences. Form 3 can be explained in accord with Azar (1964) by the production of a crude $\gamma$-globulin which, despite normal blood levels, is not completely effective resulting in defect in the small lymphocyte with the genetic information of the thymus. A single clone would be produced in potential for responding to other antigenic stimuli.

\section{Pathophysiology of the gamma system \\ Immunologically normal child: physiological variations}

There cannot be an absolute criterion of normality for the immunological state of a child just as it is not possible to measure the primary immune response to the first antigenic stimulus. Where there is a powerful antibody response to a supposedly primary stimulus it is probable that the child has had previous experience of similar antigens. We put forward five clinical criteria of normality:

History. The absence of the smallest clinical episode of an infectious nature with generalized symptoms and partial clinical expression. The levels of immunity in the experimental animal related to the existence of bacteraemia, local lesions and latent infections may be the mold for this clinical picture (Boyd, 1943).

Examination. The development of the proposed immunological scheme (Fig. 1) ascribes to it a narrow connection with the immunological development of the child, however imprecise.

Humoral. This utilizes the technique of protein fractionation for the evaluation of the immune globulins and their relation to the normal protein picture.

Biological. Measurement of the capacity for antibody production of delayed sensitivity and graft rejection.

Histological. This can be obtained by biopsy of the lymphatic organs.

Our normal subjects were selected using 1-3 and the physiological variations of immunoglobulin levels were evaluated by comparing the levels of intensity of gel precipitation lines with the quantitative values of adults (Table 1).

TABLE 1. $\gamma$-Globulin levels in children aged $0-2$ years (gel precipitation)

\begin{tabular}{crrrr}
\hline \multirow{2}{*}{ Age (months) } & \multicolumn{4}{c}{$\gamma$-Globulin } \\
\cline { 2 - 5 } & A & M & Gr & Gl \\
\hline $0-2$ & $(-)$ & $( \pm)$ & $(++)$ & $(+++)$ \\
$2-4$ & $( \pm)$ & $(+)$ & $(+)$ & $(+++)$ \\
$4-8$ & $(+)$ & $(+)$ & $(++)$ & $(+++)$ \\
$7-24$ & $(++)$ & $(++)$ & $(+++)$ & $(+++)$ \\
\hline
\end{tabular}

These values are subject to physiological variations, especially in the young infant. The newborn has values similar to those of the adult and even higher than those of the mother. The blood concentration follows a downward course from the 6th week and reaches its lowest point between the 2nd and 4th month, thereafter it rises, and reaches adult levels after 1 year. We postulate that the high concentration of $\gamma G$ of the newborn occurs at the expense of the rapid $\gamma \mathrm{G}$, which would appear to be of placental origin (de Lellis and Winckler, 1964b). It disappears progressively to a state of physiological hypoglobulinaemia between the 2 nd and 4 th month. This physiological deficit seems to occur at the expense of rapid $\gamma \mathrm{G}$.

The subsequent rise occurs as a consequence of clinical or subclinical infections. We believe that rapid $\gamma \mathrm{G}$ constitutes a molecular complex related to 
recent immunological stimuli (de Lellis \& Winckler, 1966).

$\gamma \mathbf{M}$ and $\gamma \mathrm{A}$ do not cross the placenta. The former increases rapidly in the 1st months of life and reaches adult levels at about the 9th month. The concentration of $\gamma \mathrm{A}$ follows a more regular curve and in contrast to $\gamma \mathrm{M}$ does not have the same initial rise, but is apparently absent during the 1st month and reaches adult levels after 2 years.

\section{Primary dysgammaglobulinaemias}

This term refers to the changes in the system in which immaturity, or maladjustment of the immunological integration of the child is responsible for infective symptomatology to a greater extent than the actual aetiological agent. The cyclical or recurrent nature of the episodes constitute a clear expression of the host pathology. Otherwise it must be supposed that the child is infected regularly, but fortuitously by the same or different organisms, at intervals of 20-30 days, which would be unlikely.

Using the five listed criteria, three clinical forms can be differentiated.

Symptomatology. Form 1 is febrile, Form 2 catarrhal (adenoiditis, angina, otitis, catarrhal bronchitis, pneumonias), Form 3 is one of spasmodic bronchitis.

Lymphoid tissue development. The tonsils, submaxillary nodes and the spleen are small in Form 1, variable in Form 2 and hypertrophic in Form 3, in which a hypertrophic thymus can also be seen on $\mathrm{X}$-ray.

Immunoelectrophoresis. Together with immunodiffusion serotyping will differentiate qualitatively and quantitatively the patterns characteristic of each clinical form, Form $1 \gamma \mathrm{A}, \gamma \mathbf{M}$ and $\gamma \mathrm{G}$ diminished; Form 3: $\gamma \mathrm{A}$ normal or raised, $\gamma \mathbf{M}$ absent or raised and $\gamma \mathrm{G}$ normal.

Electrophoresis. Very reduced $\gamma$-globulin in Form 1, reduced in Form 2, and normal in Form 3. Changes in the $\alpha_{1}$ - and $\alpha_{2}$-globulins in Forms 1 and 2 only.

Therapeutic. The action of $\gamma$-globulin with variations in response according to the clinical form (q.v.).

\section{Infantile malnutrition}

We will consider three grades of malnutrition up to the age of 2 years in relation to the percentage weight loss: up to $15,15-30$ and over $30 \%$. The different patterns of the $\gamma$ system make it possible to differentiate two immunological modalities which appear to be related to the dominant clinical symptomatology-that shown by malnourished patients in the first two grades (mild and moderate) and those in the third grade (severe).
In the first we have eight categories: (1) deficit of $A, M$ and $G$; (2) deficit of $A$ and $M$; (3) deficit of $M$; (4) deficit of $A$; (5) deficit of $G$; (6) increase in $A$; (7) increase in $M$; and (8) increase in $A$ and $M$.

Grades 1 and 2 both denote great variability of the immunoglobulins which is related to the clinical picture. On the other hand malnourished patients in grade 3 are characterized by reduced mobility of the $\gamma$ system with either: (1) generally increased immunoglobulins, or (2) increased $A$ and $G$ with absent M. In contrast with the first group, the symptomatology has a uniform aspect, similar from one child to the next, with predominance of focal infection and an absence of an acute septicaemic picture, occasional fever and a tendency to lymphocytosis.

The results reveal that the grade of the malnutrition determines the differential pattern of the $\gamma$ system. We suggest that the inadequate $\gamma$ system (grades 1 and 2) or adequate (grade 3) primarily or secondarily affected (dysgammaglobulinaemia of the primary and secondary type) is responsible for the grade of malnutrition. In summary, malnutrition grades 1 and 2 tend to be associated with hypoimmunoglobulinaemia and malnutrition grade 3 tends towards hyperimmunoglobulinaemia.

The possible courses of the malnutrition of the first and second grade are: (1) recovery; (2) higher mortality; (3) higher mortality before passage into the third grade; and (4) passage to the third grade. In their turn the severe malnutritions may follow a number of different courses, recovery, failure proportionally less than grades 1 and 2 , failure at a later stage, i.e. after a further attack, passage to the stage of atrophy. Children in the third grade who have gone through grades 1 and 2 of the malnutrition have increased immunoglobulin levels as they pass into the third grade.

It could not be shown that: (1) those patients in the first and second grades of malnutrition who recover do so by virtue of the hypoimmunoglobulinaemia; (2) those in the third grade had increased immunoglobulins in the second and third grades of their malnutrition: or (3) that there was a possibility of predicting the grade of involvement of the $\gamma$ system by the particular characteristics of the antigen. If alternatives (1) and (2) could be demonstrated and the third set aside, we could establish that the primary level of aptitude of the $\gamma$ system determines the grade of malnutrition.

Present information supports the hypothesis of the immune aptitude of the grade 3 malnourished subject, and is based on following evidence: (1) increased $\gamma \mathrm{A}$ is a sign of a high level of immunity; (2) the complete and constant development of rapid $\gamma G$ may represent an immature immunological immunoelectrophoretic zone in the infant; and (3) the variability of the pattern in grades 1 and 2 
signify inconstancy of response in contrast to the uniformity of grade 3. From the point of view of immune-integration these subjects suffer from an accelerated peripheralization, with a highly experienced immune system (de Lellis \& Winckler, $1966 b, 1968 b)$.
The atrophy which occurs after severe malnutrition has some features in common with the wasting syndrome which occurs in thymectomized mice and guinea-pigs (Parrot \& East, 1962; Miller, 1964). Since allogenic lymphoid cells accelerate the wasting disease a collapse of immunity with atrophy of the

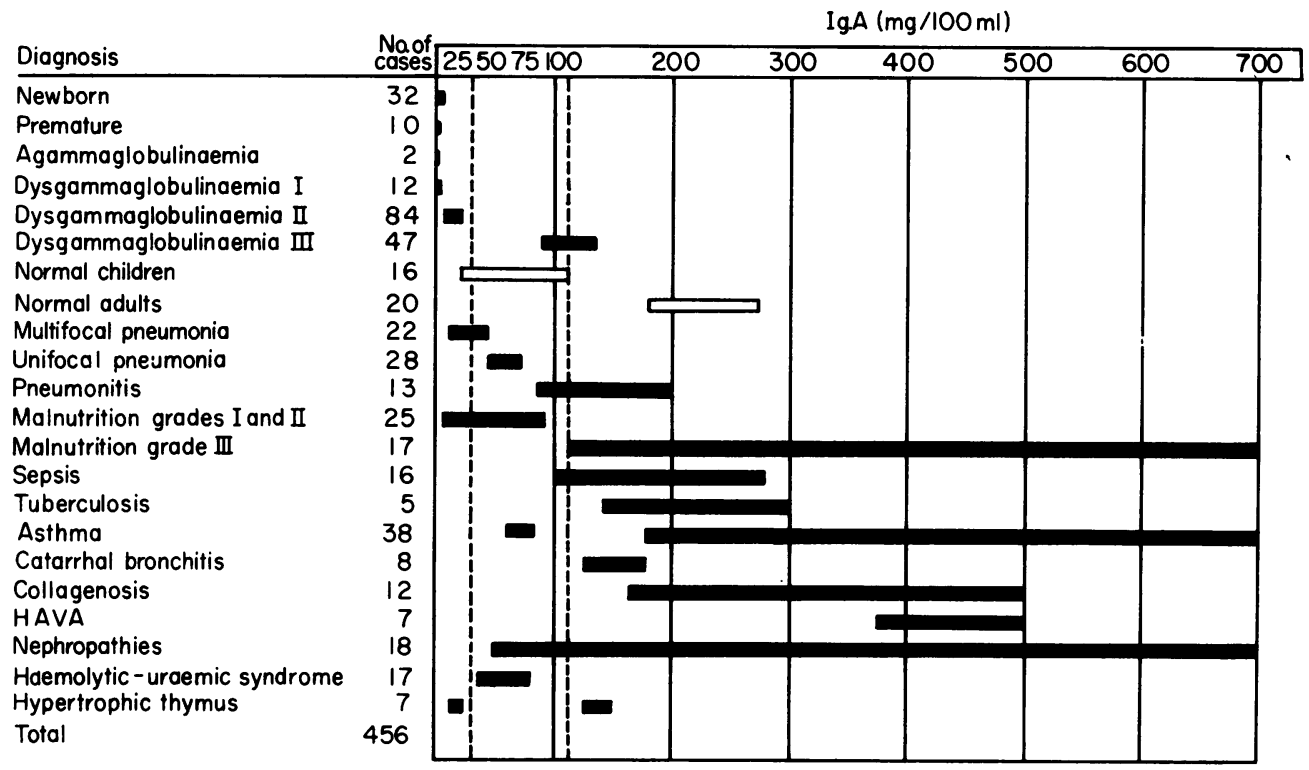

Fig. 2. Concentrations of IgA in children (Plate method).

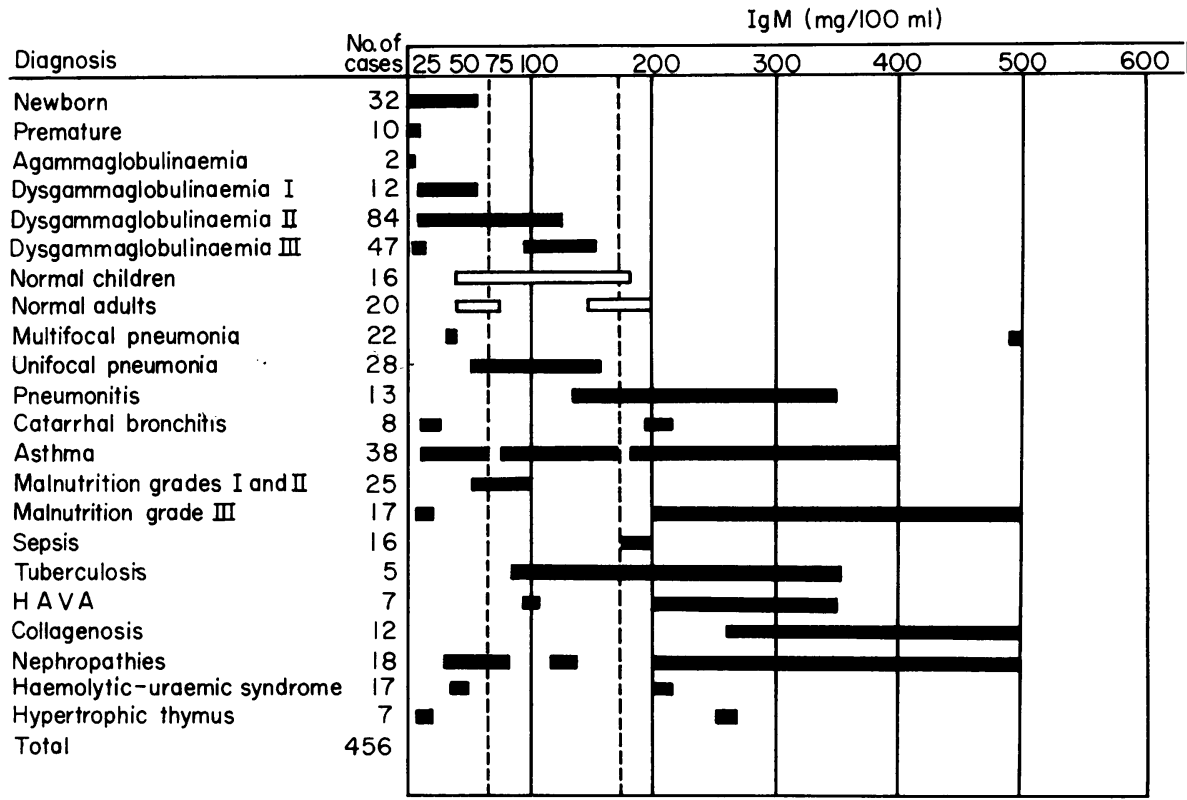

Fig. 3. Concentrations of IgM in children (Plate method). 


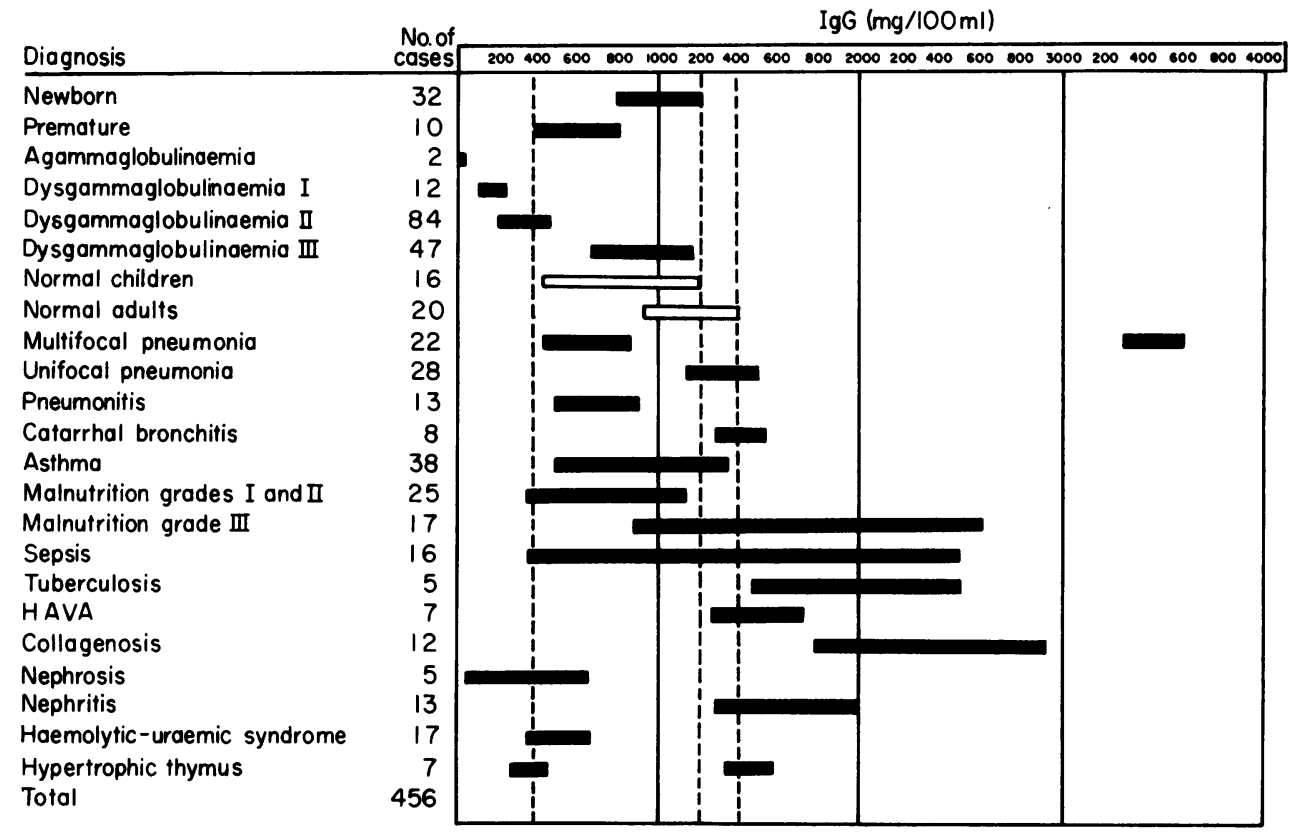

Fig. 4. Concentrations of IgG in children (Plate method).

thymus and over-peripheralization of an autoimmune mechanism is suggested (Miller, 1962). Quantitative determinations of the immune globulins in normal and pathological states are given in Figs. 2, 3 and 4, and together with observations from the literature are summarized in Fig. 5.

\section{Treatment with $\gamma$-globulin}

Our experience is based upon the use of three types of $\gamma$-globulins: (1) standard $\gamma$-globulin, obtained form Cohn's Fraction II from a pool of 10,000 donors in which the concentration and type of antibody depended upon previous immunizations and infections; (2) hyperimmune $\gamma$-globulin, obtained from donors specifically immunized against given infective diseases; and (3) intravenous $\gamma$ globulin (Gamma Venina Behringwerke), obtained by enzymatic treatment of $\gamma G$ with pepsin, with preservation of the subfractions I and II, which contain antibodies and extraction of Fraction III with antigenic and anticomplementary properties (Porter, 1959).

The therapeutic action of these $\gamma$-globulins can be attributed to four actions, specific, supplementary, additive and selective. The specific action against the microbe is based upon the provision of specific antibodies - antibacterial, antitoxins and antiviral. In these circumstances there develops a type of passive immunity which can be useful for preventive and therapeutic aims. The dose was varied for each aetiological agent in relation to the objective and for this there are established doses, both preventive and curative for measles, hepatitis, whooping-cough and mumps. This effect is most pronounced with hyperimmune $\gamma$-globulin (Cedrato \& Albores, 1964; Barandum, 1964).

The supplementary action is seen when it supplements a defective immune system: (a) agamma- and hypogammaglobulinaemia, both congenital and acquired; (b) transitory hypogammaglobulinaemias of infancy or secondary; and (c) dysgammaglobulinaemias. The supplementary action perhaps differs according to the nature of the infection.

In the agammaglobulinaemias the productive system has not been able to develop (Smith, 1960). It has been established empirically that these patients can remain free from infection with serum levels of $150 \mathrm{mg} / 100 \mathrm{ml}$. This can be achieved with doses of 0.3-0.4 ml per pound body weight, administered every 30 days (Uhr, Finkelstein \& Baumann, 1962). During the first months of treatment it is advisable to determine the blood level before each injection in order that the dose can be adjusted to a size adequate to maintain a serum level of $150 \mathrm{mg} / 100 \mathrm{ml}$.

The mechanisms postulated for the dysgammaglobulinaemias suggest the need for a qualitative rather than a quantitative therapeutic effect, and the dose frequency and duration of treatment are 


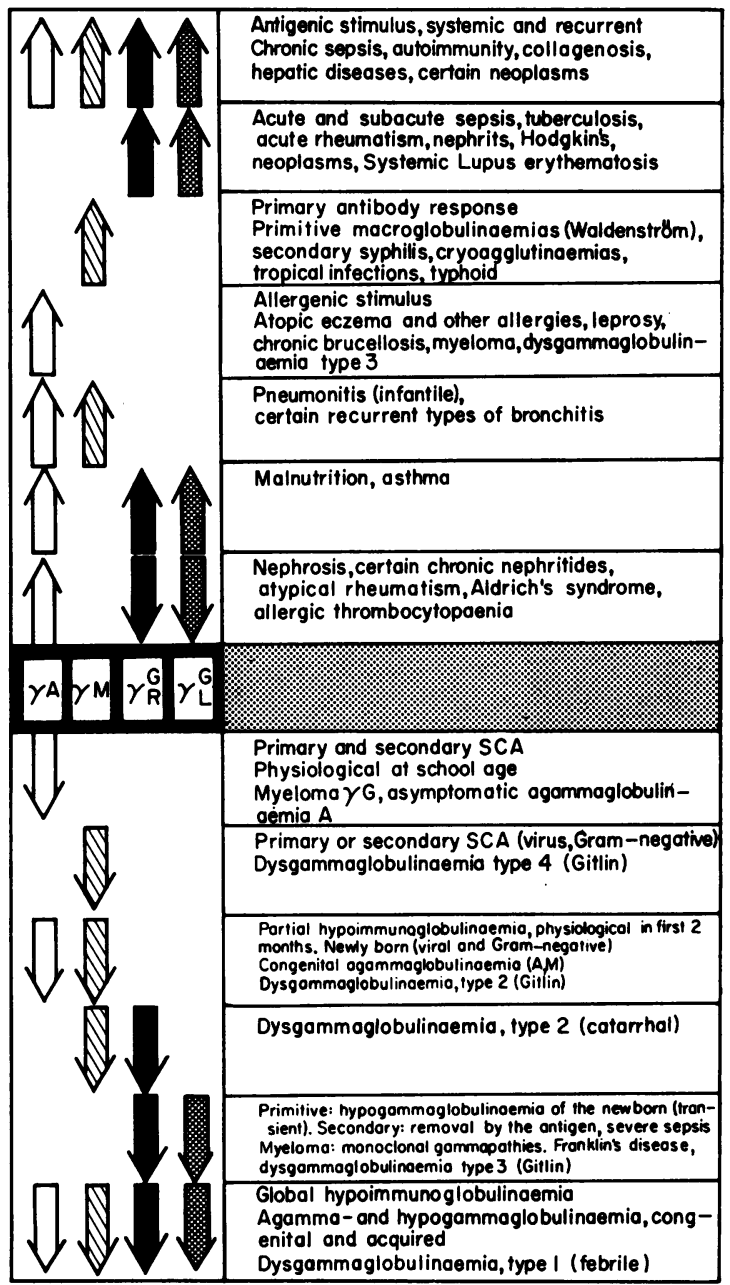

FIG. 5. Principal immunoglobulin responses.

characteristic of each clinical form to such an extent that the therapeutic effect may have diagnostic significance.

An additive action occurs where there is reinforcement of the response of the gamma system to infection. This treatment is indicated: (a) in bacterial or viral infections of whatever nature, at an early stage when the infection is extracellular; (b) in chronic and recurrent infections; and (c) in addition to treatment with corticosteroids. The action of reinforcement or of addition may be opsonizing (Hassiz 1962). $\gamma$-Globulin permits the process of degradation of bacteria phagocytosed by the leucocyte as shown, and has been shown to form a complex with both the antibody and constituent of the bacteria (Geltzer \& Suter, 1959).
The significance of the selective action is not yet fully understood but will await with increased understanding of the pathology of the $\gamma$ system. The provision of $\gamma \mathrm{A}, \gamma \mathrm{M}$ and other subfractions of standard $\gamma$-globulin would assist the elucidation of this process.

We will summarize our experience, excluding conditions in which $\gamma$-globulin was used with the hope of a specific effect.

Dysgammaglobulinaemia 1 and 2: rapid initial effect. The cycles are arrested with a single dose of about $300 \mathrm{mg}$. An equal effect can be obtained with higher doses. However, this must be repeated over a period of several months for Form 1 and every 2-3 months for Form 2.

Dysgammaglobulinaemia 3: The results are less spectacular than for the preceding forms. The maintenance of the medication every 20-30 days in doses of $320 \mathrm{mg}$ serves to prevent recurrences, though there is much individual variation as regards the speed of this effect. It is possible that this dysgammaglobulinaemia is constituted by a heterogeneous group of patients and other dysgammaglobulinaemias from this group might yet be isolated. In some cases it should be graded in relation to the aetiopathogenic mechanism of this group which differs from that of forms 1 and 2 .

Secondary hypogammaglobulinaemia: $\gamma$-Globulin has no significant action against the causes of this: (a) in the invasion of lymphoreticular tissue or the destruction or sequestration of the immunologically competent cell as in leukaemia, lymphoma and myeloma; (b) protein loss as in nephrosis, burns and the protein-losing enteropathies; and (c) immunosuppression after irradiation and immunosuppressant drugs. With the exception of nephrosis in which the $\gamma$-globulin would have no immunological role, the indication for their use lies in their important symptomatic function before the collapse of the $\gamma$ system. High doses are essential when it can be inferred that the hypoimmunoglobulinaemia is secondary to serious sepsis which initiates the mechanism of synthesis in a variable manner. The difficulty in accurately gauging the deficit caused us to use a weekly dose.

Thymic hyperplasia with hypogammaglobulinaemia: The direct relationship between the thymus and the immunoglobulins in experimental medicine is controversial, however our cases of hyperplasia with hypogammaglobulinaemia in the neonate have all been helped with this medication. The frequency and the size of the doses are similar to those recommended for the dysgammaglobulinaemias. 
Asthma: Episodes are shortened and lasting asthma is prevented. Three forms of response may be listed: those with recovery, those without change in the symptomatology, and least frequently those where symptoms are aggravated.

Haemolytic-uraemic syndrome: We have treated the hypoimmunoglobulinaemia which occurs initially with $\gamma$-globulin without untoward consequences. As yet our findings are equivocal.

Pneumonias: In the various forms of multifocal pneumonia, unifocal pneumonia pneumonitis and bronchitis, the use of $\gamma$-globulin has given excellent results. In extremely severe cases intravenous $\gamma$ globulin ( $\gamma$-venin) acted with spectacular effects. In pneumonias the best results were obtained in those that supervened upon a previous dysgammaglobulinaemia.

Malnutrition: It would seem to be indicated in the malnutritions of the first and second grades. In the third grade medication might succeed in lessening the process of accelerated peripheral distribution, and combined with anabolic agents this has produced an excellent clinical response (de Lellis et al., 1964a).

\section{References}

Albright, J.F., Capalbo, E.E., \& Makinodam, T. (1964) Some quantitative properties of antibody-producing cells. Proceedings IX Congress of the International Society of Haematology.

Archer, O.K., Pierce, J.C., Papermaster, B.W. \& Good, R.A. (1962) Reduced antibody responses in thymectomized rabbits. Nature (Lond.), 195, 191.

AsKoNAS, B.A. \& RHODES, J.M. (1965) Immunogenity of antigen-containing ribonucleic acid preparations from macrophages. Nature (Lond.), 205, 470.

Aspinall, R.L., Meyer, R.K., Graetzer, M.A. \& Wolfe, R.N. (1963) Effect of thymectomy and bursectomy on the survival of skin homografts in chickens. J. Immunol. 90, 872.

AUERBACH, R. (1966) Embryogenesis of Immune Systems: Ciba Foundation Symposium (Ed. by G. E. W. Wolstenholme), p. 39. Churchill, London.

AzAR, H.A. (1964 (The Thymus in Immunobiology (Ed. by R. A. Good and A. E. Gabrielsen), p. 432. Hoeber, New York.

BARANDUN, S. (1964) Die gammaglobulin-therapie. Bibl. Haemat. 17, 1.

BoyD, W.C. (1964) Fundamentals of Immunology, p. 3. Interscience, New York.

Brent, L. \& Gowland, G. (1963) Conceptual Advances on Oncology and Immunology (Ed. by M. D. Anderson), p. 335. Hoeber, New York.

BRYANT, B.J. (1962) Reutilization of leukocyte DNA by the cells of regenerating liver. Exp. Cell Res. 27, 70.

BURNET, F.M. (1961) The new approach to immunology. New Engl. J. Med. 264, 24.
Camblin, J.G. \& Bridges, J.B. (1964) Effects of cell-free extracts of thymus in leucopoenic rats. Transplantation, 2, 785.

Cedrato, A.E. \& Albores, J.M. (1964) Uso e indicaciones de las gammaglobulinas. Fichero Medico Terapeutico Purissimus. Edicion especial XXVI.

Clark S.L. Jr. (1966) The Penetration of Proteins of Colloidal Materials into the Thymus from the Blood Stream. Ciba Foundation Symposium (Ed. by G. E. W. Wolstenholme), p. 3. Churchill, London.

Claman, H.N., \& Talmage, D.W. (1963) Thymectomy, prolongation of immunological tolerance in the adult mouse. Science, 141, 1193.

Congdom, C.C. \& DudA, D.B. (1961) Precention of bone marrow heterografting. Arch. Path. 71, 311.

DamesheK, W. (1966) The Thymus: Experimental and Clinical Studies: Ciba Foundation Symposium (Ed. by G. E. W. Wolstenholme), p. 399. Churchill, London.

Deffendi, V., Roosa, R.A. \& Koprowski, A. (1964) The Thymus in Immunobiology (Ed. by R. A. Good and A. E. Gabrielsen), p. 504. Hoeber, New York.

De Lellis, R.H., Leveratto, I., Dimari, N., Mascardi, N. \& LANGLEY, R. (1964a) Anabolicos en distroficos graves. Il Jornades Argentinas de Puericultura. Cordoba.

DE Lellis, R.H. \& Winckler, J.A. (1966a) Estudio de la fraccion rapida de la gamma $G$ globulina por immunoelectroforesis, su significacion en el desarrollo de la maduracion inmunologica del lactante. Arch. Arg. Pediat. 65,$7 ; 100$.

DE LELLIS R.H. \& WiNCKLER, J.A. (1966b) El sistema gamma en el nino distrofico. Arch. Arg. Pediat. 65, 7; 108.

DE Lellis, R.H. \& WincKLeR, J.A. (1968a) Drei formen dysgammaglobulinamie des saugling. Die Gelben Hefte, 14,635 .

DE Lellis, R.H. \& Winckler, J.A. (1968b) Estudios preliminares papa un diagnostico immunologico de las enfermedades respiratorias bajas de las infancia. Soc. Arg. Pediat. (In press).

DE LeLlis, R.H. \& WincKLeR, J.A. (1967) Fisiopathologia del sistema gamma en pediatria. Gaceta Sanitaria, 4, 131.

DE Lellis, R.H. Winckler, J.A. \& Yanez, M. (1964b) Immonoelectroforesis de las proteinas sericas del recien nacido normal. Pediat. panamer. 90, 102.

DOUGHERTY, R.F. (1952) Effect of hormones on lymphoplastic tissue. Physiol. Rev. 32, 379.

Dustin, A.P. \& Gregoire, C. (1931) Contribution à l'étude de la mitose dimunitive ou elassotique dans les thymus des mamifères. C.R.Soc. Biol. (Paris), $108,1159$.

Dutton, R.W., Eady, J.D. \& Belman, H.N. (1963) The antigenic stimulation of DNA synthesis in spleen cells from immunized rabbits. Conceptual Advances in Immunology and Oncology (Ed. by M. D. Anderson), p. 98. Hoeber, New York.

EveretT, N.B., Rieke, W.O. \& Caffrey, R.W. (1964) The kinetics of small lymphocytes in the rat. Thymus in Immunobiology (Ed. by R. A. Good \& A. E. Gabrielsen), p. 291. Hoeber, New York.

Feldman, M. \& MeKori, T. (1966) Antibody production by cloned cell population. Immunology, 10, 149.

Fichtelius, K.E. \& BRyANT, B.J. (1964) On the fate of thymocytes. The Thymus in Immunobiology (Ed. by R. A. Good and A. E. Gabrielsen), p. 274. Hoeber, New York.

Fichtelius, K.E. \& Diderholm, H. (1959) Transfusion of labelled thymus lymphocytes in rats under secondary response to $S$. typhi H. antigen. Acta path. microbiol. scand. 47, 304.

Fischman, M. \& Alder, F.L.J. (1963) J. exp. Med. 177, 595. 
FORD, C.E. (1966) Traffic of Lymphoid Cells in the Body: Ciba Foundation Symposium (Ed. by G. E. W. Wolstenholme), p. 131. Churchill, London.

Ford, C.E. \& MiCKLEM, H.S. (1963) The thymus and lymphnodes in radiation chimeras. Lancet, $\mathbf{i}, 359$.

Ford, W.L., Gowans, J.L. \& MCCullaGH, R.J. (1966) The Thymus, Experimental and Clinical Studies. Ciba Foundation Symposium (Ed. by G. E. W. Wolstenholme), p. 58. Churchill, London.

Friedman, H.P., Stavitsky, A.B. \& Solomon, J.M. (1965) Induction in vitro of antibody to phage T 2 antigens in the DNA extract employed. Science, 149, 1106.

Geltzer, J. \& Suter, E.J. (1964) Exp. Med. 110, 715.

Gluberson, A. \& AuERBACH, R. (1964) Interaction of mouse lymphoid tissues in vitro. Science, 146, 425.

Good, R.A. \& PAPermaster, B.W. (1964) Ontogeny and phylogeny of adaptive immunity. Advanc. Immunol. 1, 4.

GoRDON, H.A. (1959) Morphological and physiological characterization of germ free life. Ann. N.Y. Acad. Sci. 78, 208.

GowaNs, J.L. (1964) The migration of lymphocytes into lymphoid tissue. The Thymus in Immunobiology (Ed. by R.A. Good \& A.E. Gabrielsen), p. 255. Hoeber, New York.

Gregoire, C.H. \& Duchateau, G.H. (1956) Arch. Biol. 67, 259.

HARRIS, J.E. \& Ford, C.E. (1964) Nature (Lond.), $201,884$.

HASSIG, A. (1962) Hemotherapia con fracciones plasmaticas. Triangulo, 5, 240.

Heremans, J.F. (1960) Les Globulines Seriques du Systsme Gamma. Aracia, Bruxelles.

JACOB, J. \& MoNOD, J. (1961) Genetic regulatory mechanisms in the synthesis of proteins. J. molec. Biol. 3, 318.

Klein, J.J., Goldstein, A.L. \& White, A. (1965) Enhancement of in vitro incorporation of labeled precursors into DNA and total protein of mouse lymph nodes after administration of thymus extracts. Proc. nat. Acad. Sci. (Wash.), 53, 812.

KuniI, A., Furth, J. \& Berwick, L. (1966) The Thymus, Experimental and Clinical Studies. Ciba Foundation Symposium (Ed. by G. E. W. Wolstenholme). Churchill, London.

Leduc, E.H., Coons, A.H. \& Connoly, J.M. (1955) The primary and the secondary response in the popliteal lymph node of the rabbit. J. exp. Med. 102, 61 .

Leuchars, E., Davis, J. \& Koller, P. (1966) Ciba Foundation Symposium (Ed. by G. E. W. Wolstenholme), p. 173. Churchill, London.

Levey, R.H., Trinin, J. \& LAy, L.W.J. (1963) Nat. Cancer Inst. 31, 199.

MaCKay, I.R. \& Burnet, F.M. (1963) Autoimmune Disease, p. 31. Thomas, Springfield, Illinois.

Makinodan, T. \& Peterson, W.J. (1967) Relative antibody forming capacity of spleen cells as a function of age. Proc. nat. Acad. Sci. (Wash.) 48, 234.

McFarland, W. \& HeilmanN, D.H. (1965) Lymphocyte foot appendage: its role in lymphocyte function and immunological reaction. Nature (Lond.), 205, 887.

MetCalfe, D. (1956) The thymic origin of the plasma lymphocytosis stimulating factor. Brit. J. Cancer, 10, 442.

Metcalfe, D. (1964) The thymus and lymphopoiesis. The Thymus in Immunobiology (Ed. by R. A. Good \& A. E. Gabrielsen), p. 150. Hoeber, New York.

Metcalfe, D. (1966) The Thymus, Experimental and Clinical Studies. Ciba Foundation Symposium (Ed. by G. E. W. Wolstenholme), p. 242. Churchill, London.

Miller, J.F.A.P. (1961) Immunological function of the thymus. Lancet, ii, 748.

Miller, J.F.A.P. (1962) Role of the thymus in transplantation tolerances and immunity. Ciba Foundation Symposium:
Transplantation (Ed. by G. E. W. Wolstenholme and M. P. Cameron), p. 384. Churchill, London.

Miller, J.F.A.P. (1964) Thymic ablation and replacement. The Thymus in Immunobiology (Ed. by R. A. Good and A. F. Gabrielsen), p. 455, Hoeber, New York.

Miller, J.F.A.P., Marshall, A.H.E. \& White, R.G. (1962) The immunological significance of the thymus. Advanc. Immunol. 2, 111.

Nossal, G.J.V. (1964) The Thymus in Immunobiology (Ed. by R. A. Good and A. E. Gabrielson), p. 731. Hoebor, New York.

Nossal, G.J.V., AdA, G.L. \& Austin, G.M. (1964) Antigens in immunity, 11 immunogenic properties of flagella, polymerized flagellin and flagellin in the primary response. Aust. J. exp. Biol. med. Sci. 42, 311.

Nossal, G.J.V. \& MaKela, O. (1962) DNA synthesis amongst simple antibody producing cells. J. exp. Med. 115, 231.

Nossal, G.J.V. \& Mitchell, J. (1966) The Thymus in Relation to Immunological Tolerance: Ciba Foundation Symposium (Ed. by G. E. W. Wolstenholme), p. 105. Churchill, London.

Osoba, D. \& Miller, J.F.A.P. (1964) The lymphoid tissues and immune responses of neonatally thymectomized mice bearing thymus tissue in milliposr diffusion chambers. J. exp. Med. 119, 177.

Parrot, D.M. \& EAST, J. (1962) The role of the thymus in neonatal life. Nature (Lond.), 195, 347.

Peetom, P. (1963) Agar Precipitation Technique and its Application as a Diagnostic and Analytical Method. Thomas, Springfield, Illinois.

PORTER, R.R. (1959) The hydrolysis of rabbit gammaglobulin and antibodies with crystalline papain. J. Biochem. 73, 119.

Rosen, F.S., Kevy, S.V., Merler, E., Janeway, C.A. \& GitLiN, D. (1961) Recurrent bacterial infections and dysgammaglobulinemia: deficiency of 7-S gammaglobulin in the presence of elevated 19-S gammaglobulin. Pediatrics, 28, 182.

SAHIAR, K. \& SchWARTz, R.S. (1964) Inhibition of antibody synthesis by 7-S antibody. Science, 145, 395.

Sainte Marie, G. \& Leblond, C.P. (1964) Thymus cell population dynamics. The Thymus in Immunobiology (Ed. by R. A. Good and A. E. Gabrielsen), p. 207. Hoeber, New York.

Schodley, H.E. (1961) Colloquium der gesellsch. J. physiol. chem. Mosbach (Baden), 9, 12.

Schultze, H.E. (1959) Colloquium der Gesellsch. Vol. 9, p. 12. Mosbach, Baden.

ScHwICK, J.G. (1966) VI Internationaler Kongress fur Klinische Chemic. Munchen.

SMITH, R.T. (1960) Cellular Basis of Antibody Formation: Ciba Foundation Symposium (Ed. by G. E. W. Wolstenholme). Churchill, London.

STERzL, J. (1966) The Thymus, Experimental and Clinical Studies: Ciba Foundation Symposium (Ed. by G. E. W. Wolstenholme), p. 36. Churchill, London.

STONER, R.D. \& Bond, V.P. (1963) Antibody formation by transplanted bone marrow, spleen, lymph nodes and thymus cells in irradiated recipients. J. Immunol. 91, 185.

Talmage, D.W. \& Claman, H.N. (1964) Cell potential, its mutation and selection. The Thymus in Immunobiology (Ed. by R. A. Good and A. E. Gabrielsen), p. 49. Hoeber, New York.

TAYLOR, R.B. (1963) Immunological competence of thymus cells after transfer to thymectomized recipients. Nature (Lond.), 199, 873.

Uhr, J.W., Finkelstein, M.S. \& BaumanN, J.B. (1962) Antibody formation. The primary and secondary antibody response to bacteriophage $\Phi \mathrm{X}-174$ in guinea pigs. $J$. exp. Med. 115, 655. 
Yi-Chuan Ching, Davis, S.D. \& Wedgewood, A. (1966) Antibody studies in hypogammaglobulinaemia. J. clin. Invest. 10, 1593.
Yunis, E.J., Hilgard, H., Suodin, K., Martinez, G. \& GooD, R.A. (1964) Immunological reconstitution of thymectomized mice by injections of isolated thymocytes. Nature (Lond.), 201, 784. 